\begin{tabular}{|l|l|}
\hline $\begin{array}{l}\text { 2. To: (Recelving Organization) } \\
\text { Distribution }\end{array}$ & $\begin{array}{l}\text { 3. From: (Originating Organization) } \\
\text { WFD Project Procedures }\end{array}$ \\
\hline $\begin{array}{l}\text { 5. Proj./Prog./Dept./Div.: } \\
\text { WFD Project }\end{array}$ & $\begin{array}{l}\text { 6. Design Authority/Design Agent/Cog. Engr.: } \\
\text { DP Lund }\end{array}$ \\
\hline
\end{tabular}

8. Originator Remarks:

For Approval and release.

11. Receiver Remarks:

11A. Design Baseline Document? $\square$ Yes $\square$ No

4. Related EDT No:

$\mathrm{N} / \mathrm{A}$

7. Purchase Order No::

$\mathrm{N} / \mathrm{A}$

9. Equip./Component No.:

$\mathrm{N} / \mathrm{A}$

10. System/Bldg./Facility:

$\mathrm{N} / \mathrm{A}$

12. Major Assm. Dwg. No.:

$\mathrm{N} / \mathrm{A}$

13. Permit/Permit Application No.:

$\mathrm{N} / \mathrm{A}$

14. Required Response Date:

\begin{tabular}{|c|c|c|c|c|}
\hline 15. & & DATA TR & NSMITT & \\
\hline $\begin{array}{c}(\text { A) } \\
\text { liem } \\
\text { No. }\end{array}$ & (B) Document/Drawing No. & $\begin{array}{l}\text { (C) Sheet } \\
\text { No. }\end{array}$ & $\begin{array}{l}\text { (D) Rev. } \\
\text { No. }\end{array}$ & (E) Title or Description of Data Transmitted \\
\hline 1 & RPP -6926 & & 0 & DST \& WFD BM Quality MAP \\
\hline • & & & & \\
\hline & & & & \\
\hline & & & & \\
\hline & & & & \\
\hline & & & & \\
\hline
\end{tabular}

16.

KEY

\begin{tabular}{|c|c|c|c|}
\hline (F) & $(G)$ & $(H)$ & $(I)$ \\
\hline $\begin{array}{c}\text { Approval } \\
\text { besig- } \\
\text { nator }\end{array}$ & $\begin{array}{c}\text { Reason } \\
\text { for Trans- } \\
\text { mittal }\end{array}$ & $\begin{array}{c}\text { Origi- } \\
\text { nator } \\
\text { Dispo- } \\
\text { stion }\end{array}$ & $\begin{array}{c}\text { Receiv- } \\
\text { er } \\
\text { Dispo- } \\
\text { sition }\end{array}$ \\
\hline N/A & 1 & 1 & 1 \\
\hline & & & \\
\hline & & & \\
\hline & & & \\
\hline & & & \\
\hline
\end{tabular}

Approval Designator (F)

Reason for Transmittal (G)

\begin{tabular}{|ll}
$|c|$ & \multicolumn{1}{c}{ Disposition (H) \& (I) } \\
$\begin{array}{ll}\text { 1. Approved } & \text { 4. Reviewed no/comment } \\
\text { 2. Approved w/comment } & \text { 5. Reviewed w/comment } \\
\text { 3. Disapproved w/comment } & \text { 6. Receipt acknowledged }\end{array}$ \\
\hline
\end{tabular}
E, S, O, D OR N/A Sec. 12.7)

4. Review

5. Post-Review

6. Dist. (Receipt Acknow. Required)

3. Disapproved w/comment

SIGNATUREIDISTRIBUTION

17.

(See Approval Designator for required signatures)

\begin{tabular}{|c|c|c|c|}
\hline $\begin{array}{l}\text { (G) } \\
\text { Rea- } \\
\text { son }\end{array}$ & $\begin{array}{l}(\mathrm{H}) \\
\text { Disp. }\end{array}$ & (K) Signature & (L) Date (M) MSIN \\
\hline & & Design Authority & \\
\hline & & Design Agent & \\
\hline 1 & 1 & Cog. Eng. D.P. Lund & ne $8 / 30 / 00 \mathrm{R} 3-25$ \\
\hline 1 & 1 & Cog. Mgr. R.W. Root & $R 2-50$ \\
\hline & & QA & \\
\hline & & Safety & \\
\hline & & Env. & \\
\hline
\end{tabular}

18

Bolund

D.P. Lund

Signature of EDT

Originator
19

$\mathrm{N} / \mathrm{A}$

Authorized Representative for Receiving Organization

\begin{tabular}{|c|c|c|}
\hline $\begin{array}{l}\text { (G) } \\
\text { Rea- } \\
\text { son }\end{array}$ & $\begin{array}{l}\text { (H) } \\
\text { Disp. }\end{array}$ & (J) Name \\
\hline & 3 & C.A. Rieck \\
\hline & 3 & C.E. Shipler \\
\hline & 3 & J.W. Lentsch \\
\hline & 3 & G.P. Duncan \\
\hline & 3 & K.N. Jordan \\
\hline & 3 & G.W. McLellan \\
\hline & 3 & M.D. Harding \\
\hline \multicolumn{3}{|l|}{20.} \\
\hline $\begin{array}{l}\text { Desig } \\
\text { Cogn }\end{array}$ & $\begin{array}{l}\text { Auth } \\
\text { ant }\end{array}$ & ty ${ }^{\prime}$ \\
\hline
\end{tabular}

(K) Signature

(L) Date

(M) MSIN

R3-47

s2-25

R3-25

R3-72

R3-25

R3-47

s0-09

21. DOE APPROVAL (if required) Cirl No.

$\square$ Approved

$\square$ Approved w/comments

$\square$ Disapproved w/comments BD.7400-172-9 


\section{Double Shell Tanks and Waste Feed Delivery Project Management Quality Affecting Procedures Management Assessment Plan}

CH2M HILL Hanford Group, Inc.

Richland, WA 99352

U.S. Department of Energy Contract DE-AC06-99RL14047

$\begin{array}{lll}\text { EDT/ECN: } & \text { EDT-630201 } & \text { UC: N/A } \\ \text { Cost Center: CL60000 } & \text { Charge Code: } 101872 \\ \text { B\&R Code: } & \text { N/A } & \text { Total Pages: } \alpha 2\end{array}$

Key Words: Project Management, Quality Affecting Procedures, Management Assessment Plan, assessments, DST \& WFD, project

Abstract: The purpose of the Double Shell Tanks (DST) and Waste Feed Delivery (WFD) Management Assessment Plan is to define how management assessments within DST \& WFD will be conducted. The plan as written currently includes only WFD Project assessment topics. Other DST \& WFD group assessment topics will be added in future revisions.

TRADEMARK DISCLAIMER. Reference herein to any specific commercial product, process, or service by trade name, trademark, manufacturer, or otherwise, does not necessarily constitute or imply its endorsement, recommendation, or favoring by the United States Government or any agency thereof or its contractors or subcontractors.

Printed in the United States of America. To obtain copies of this document, contact: Document Control Services, P.O. Box 950, Mailstop H6-08, Richland WA 99352, Phone (509) 372-2420; Fax (509) 376-4989.

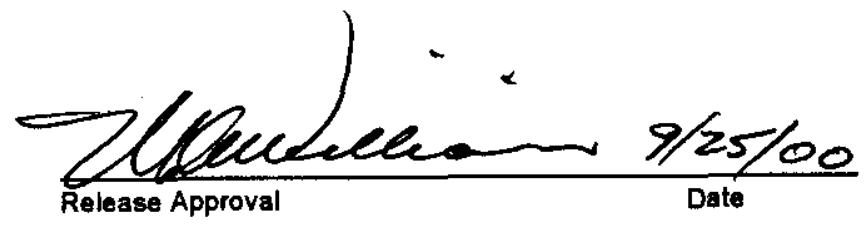

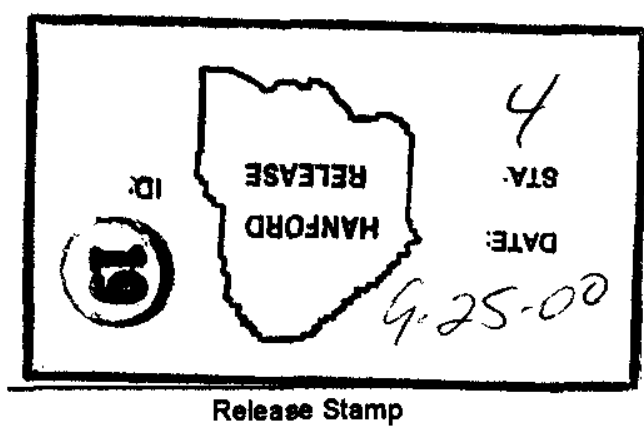

Release Stamp 


\section{Double Shell Tanks and Waste Feed Delivery Project Management Quality Affecting Procedures Management Assessment Plan}

\section{Purpose:}

10 CFR 830.120, Quality Assurance Requirements and DOE O 414.1A, Quality Assurance require (1) managers to assess their processes and (2) problems that hinder achievement of objectives be identified and corrected.

The purpose of the Double Shell Tanks and Waste Feed Delivery (DSTMFD) Project Management Assessment Plan is to define how management assessments of sub-projects within DSTMFD will be conducted. This plan identifies the management assessment program scheduling, process, performance criteria, roles and responsibilities, training, reporting, follow-up and verification activities, and records to be retained.

The primary goal of this program is to encourage managers to spend time with their employees (or subcontractors) during work execution, making them visible and accessible to personnel performing work. Time spent in this manner allows managers to observe work practices and barriers to work performance. It also makes managers accessible to personnel performing work who can provide valuable suggestions for work process improvement.

Therefore, the primary purpose for performing management assessments on sub-projects within DSTMFD is to identify management systems and work processes affecting work performance and make improvements to ensure the achievement of DSTMFD Project objectives. Observing work and conducting interviews should take precedence over the examination of relevant documentation. Management assessments should look at how well a management system or work process as a whole, or how internal, lower-level management subsystems or work processes or portions of management subsystems or work processes allow customer requirements and expectations to be met.

Documented proof of project compliance with project quality affecting procedures is an important secondary benefit resulting from the performance of management assessments. Subcontractor support considered to be a government furnished service (such as Fluor Daniel Hanford, or Fluor Federal Services) will have compliance assessments performed by the Department of Energy. Therefore, any management assessments performed on government furnished services should focus upon work process improvement. Management assessments performed on subcontractors not considered to be a government furnished service may have a broader scope than process improvement since noncompliance with Quality affecting procedures may have an adverse effect upon the project end products and goal achievement.

\section{Roles and Responsibilities:}

\section{DSTMFD Project Director:}

1. Develops an annual assessment schedule describing the project specific assessment topic, project and assessment timing for performance in accordance with HNF-IP-0842, Volume I, Section 2.10 attachment A. The schedule can be changed or augmented at management's discretion based on current conditions, needs and priorities. 
2. Reviews assessment results to:

- Determine the effectiveness of management or work processes

- Ensure nonconformance and noncompliance resolution

- Perform trend analysis

- Ensure corrective actions are processed in accordance with HNF-IP-0842, Volume I, Section 2.4, "Corrective Action Management."

- Ensure Lessons Learned are generated in accordance with HNF-IP-0842, Volume II, Section 4.6.3, "Lessons Learned Program Procedure."

3. Publishes a quarterly report to the Senior Vice President and Project Manager of DSTMFD, with copies to the Executive Vice President and Deputy General Manager and Quality Assurance Director by the twentyfifth of the month following the end of the quarter for those assessments identified in the annual schedule.

4. Routes a copy of assessment reports to the Price Anderson Amendment Act Manager in accordance with HNF-IP-0842, Volume I, Section 1.5, "Price Anderson Amendment Act Evaluation and Reporting."

Individual managers:

1. Complete management assessments in accordance with the assessment schedule or as directed by the DSTMFD Project Manager.

2. Immediately act on any safety concerns observed during assessments.

3. Document assessment results and turn in a report to DSTMFD Project management.

4. Ensure entry of deficiencies into the Corrective Action Management System in accordance with HNF-IP-0842, Volume I, Section 2.4, "Corrective Action Management."

5. Resolve non-conformances and non-compliances and perform corrective action follow-up and verification to close corrective actions and.

6. Develop Lessons Learned as necessary in accordance with HNF-IP-0842, Volume II, Section 4.6.3, "Lessons Learned Program Procedure."

\section{Process:}

The annual assessment schedule and management assessments shall be performed in accordance with HNF-IP-0842, Volume I, Section 2.10.

\section{Personnel qualifications and training:}

Completion of management assessment training (course \#350315) is encouraged, but not required.

\section{Performance Criteria and Reporting:}

Attachment 1 contains a sample assessment report format that should be used to document management assessments. Depending upon the assessment topic, other forms in HNF-IP-0842, Volume I, Section 2.10, attachment $F$ may be substituted in place of this form.

Performance criteria are found in those project procedures judged to be quality affecting. Attachment 2 contains a list of quality affecting procedures along with key requirements that will form the topic of the assessments. 
RPP-6926, Revision 0

Although a schedule has been developed and a minimum number of management assessments assigned to individual managers, managers may request assessment topic substitutions and perform assessments on other topics provided DSTMFD Project Director approval is obtained.

\section{Follow-up and verification activities:}

Deficiencies noted during management assessments must be entered into the Corrective Action Management (CAM) System in accordance with HNF-IP-0842, Volume I, Section 2.4, "Corrective Action Management." Assessments are due the last day of the month in which they are scheduled.

Managers are responsible to follow-up on the implementation of recommended corrective actions to ensure that deficiencies have been corrected and CAM corrective actions are closed. Managers are responsible to provide corrective action implementation status at least 2 weeks prior to development of the quarterly management assessment report so the status can be included in the report.

Managers are responsible to develop Lessons Learned as necessary in accordance with HNF-IP0842, Volume II, Section 4.6.3, "Lessons Learned Program Procedure."

\section{Records to be retained:}

DSTMFD Project management shall retain the original management assessments reports and quarterly management assessment reports. These documents shall be retained until the cycle is completed and new assessment reports and quarterly management assessment reports covering the same assessments are performed.

\section{Schedule:}

Managers shall perform assessments in accordance with the annual assessment schedule. The assessment schedule will be distributed annually, with updates occurring per management discretion. Deviation from the assessment schedule will be allowed provided the approval of the DSTMFD Project Director is obtained.

Attachment 2 provides a list of assessment topics based upon the project procedures judged to be quality affecting and will form the basis for DSTMFD Project management assessments. The list includes: the priority; procedure title; procedure number; item paragraph and title; the requirement or requirements judged to be critical to successful compliance with the procedure; and the assessment topic. The generation of the DSTMFD Project annual assessment schedule will be accomplished by assigning individual manager names and completion dates to each assessment topic. Initially, assessments will be scheduled in the order of their importance.

To encourage participation in this program, management assessment topics and scope were chosen with the goal that they should require no more than 1 day for their execution. In some cases, this goal may not have been achieved, and more time may be required. Assessments which take more than 1 day to complete, should be identified to the DSTMFD Project management so their scope can be further divided. Note: when deficiencies are noted, it is expected that additional effort may be required to identify, initiate, and follow -up/monitor corrective actions and ensure proper action item closure. 
RPP-6926, Revision 0

\section{Attachment 1}

Management Assessment Report Format

\begin{tabular}{|l|l|l|}
\hline Name: & \multicolumn{2}{|c|}{ Date: } \\
\hline REQUIREMENT & REQUIREMENT & $\begin{array}{l}\text { OBJECTIVE EVIDENCE EXAMINED } \\
\text { (Documents reviewed, personnel interviews, etc.) }\end{array}$ \\
\hline & & \\
& & \\
& & \\
& & \\
& & \\
& &
\end{tabular}

Assessment Results: (Discuss observations, issues discovered, deficiencies, and noteworthy practices. Please be sure to discuss any condition adverse to quality in sufficient detail to enable corrective action to be taken.)

Assessment Conclusions: (Discuss conclusions regarding performance/effectiveness/areas of improvement or compliance.) 


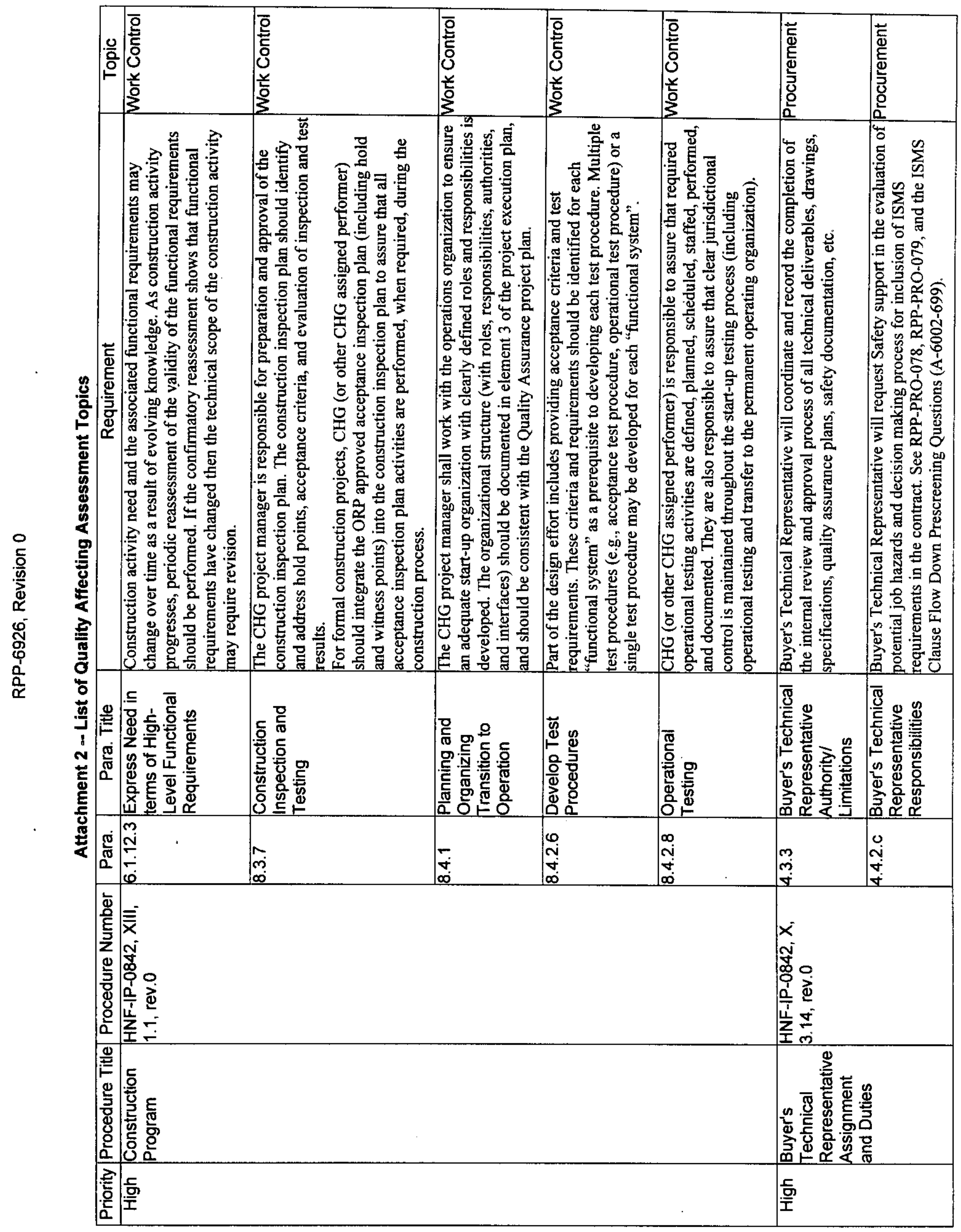




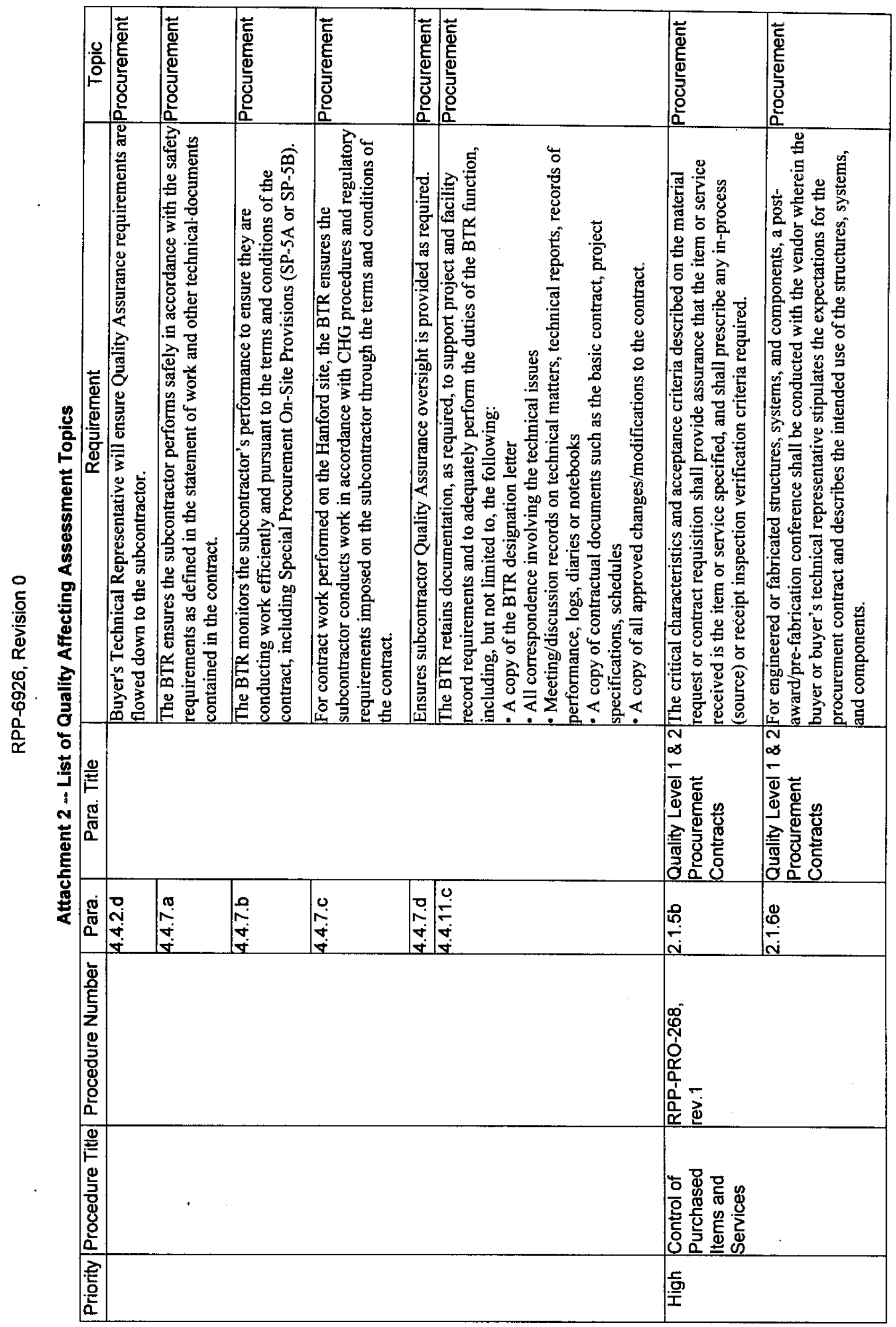




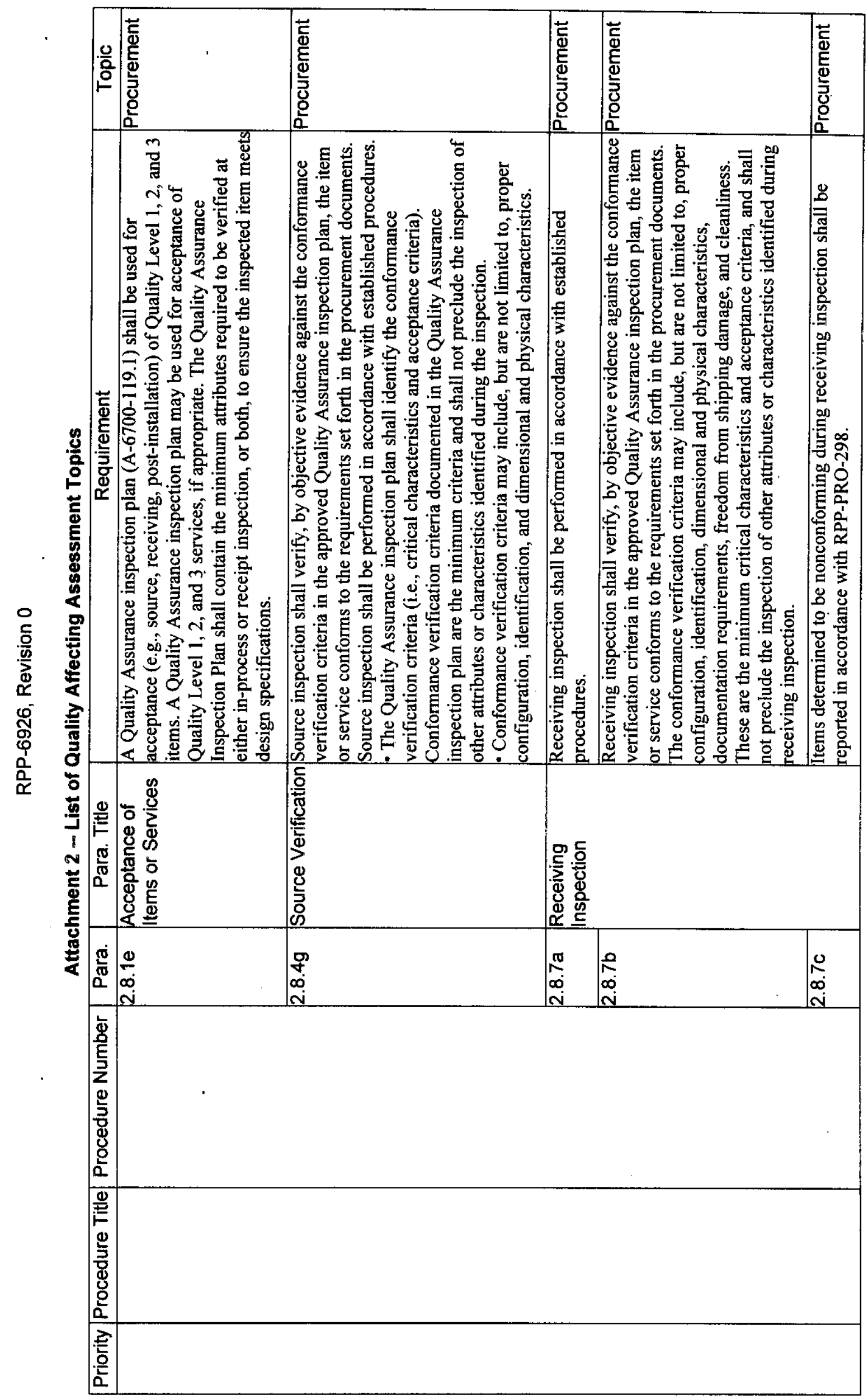




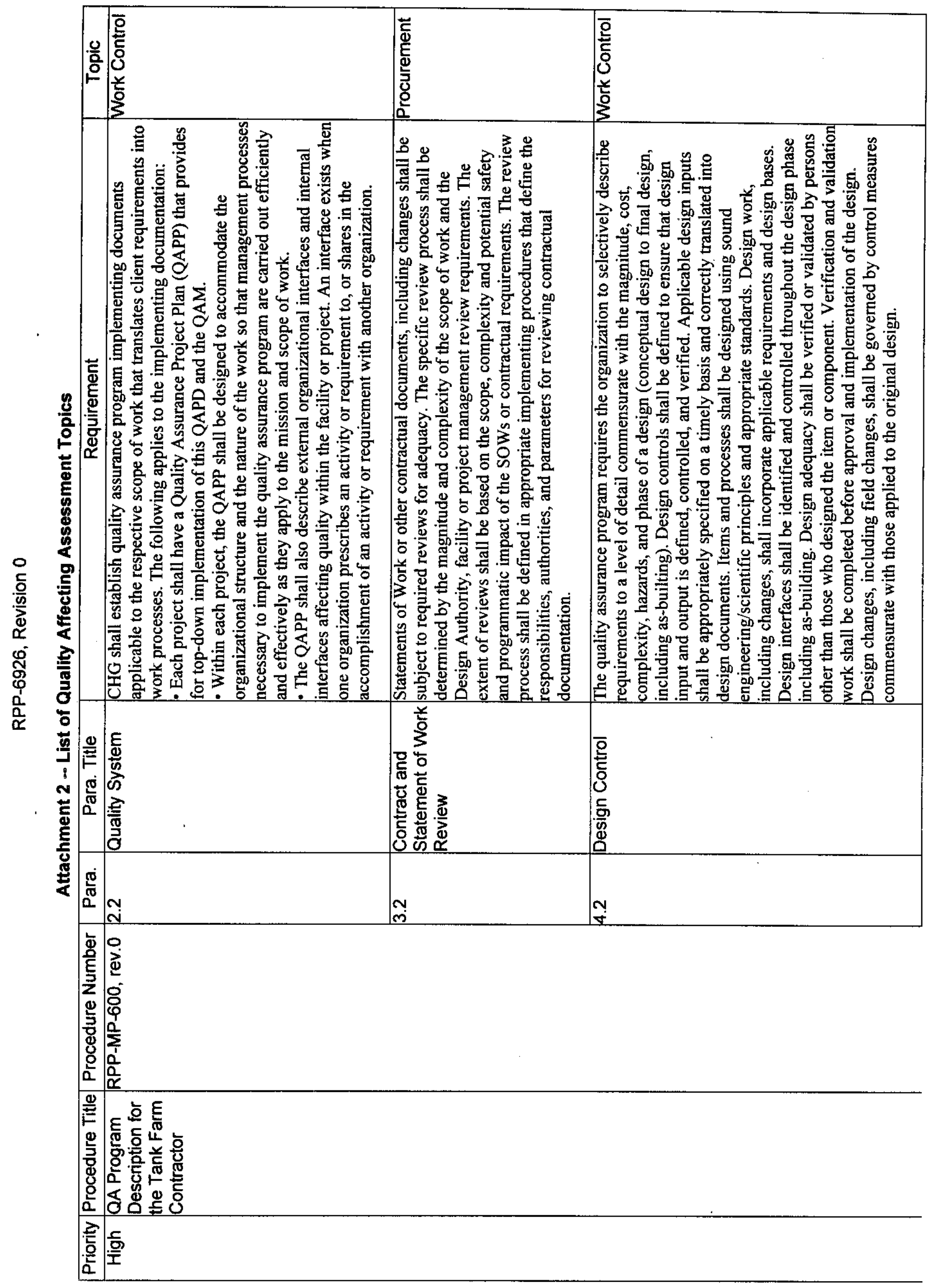




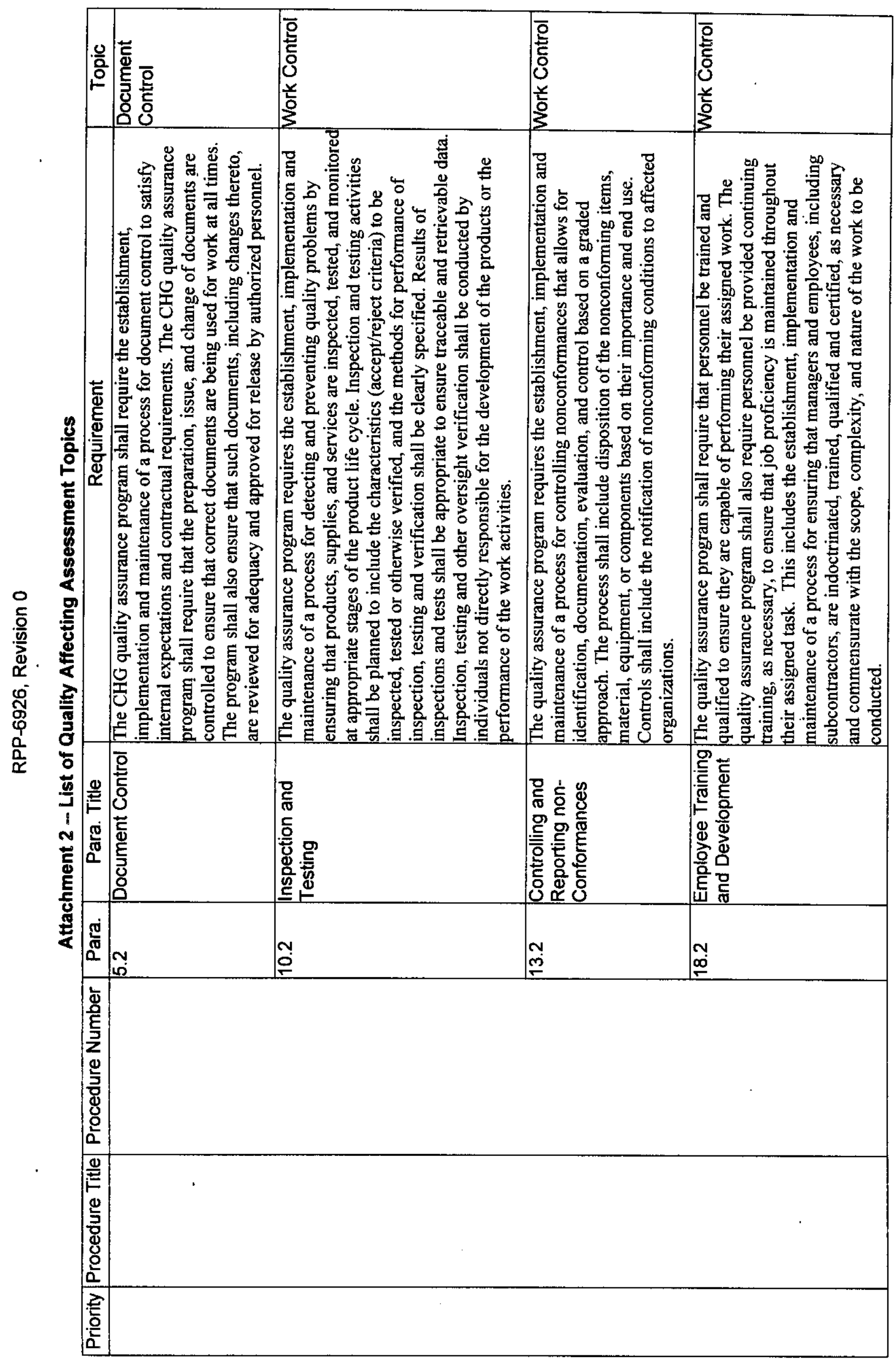




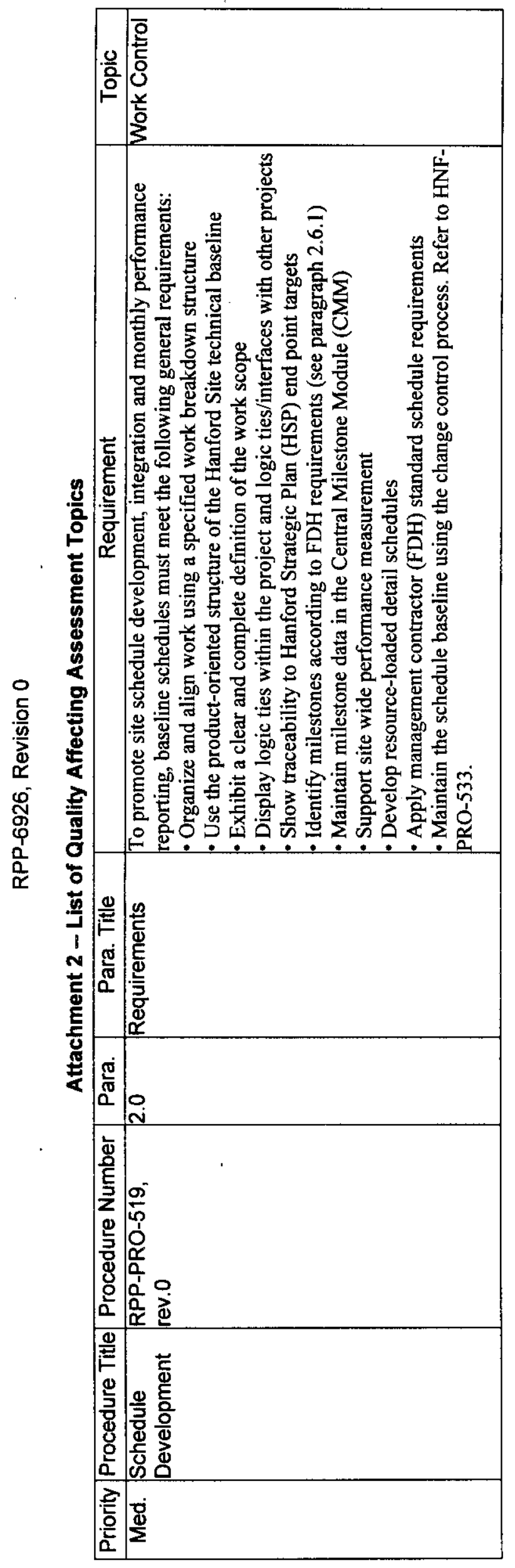




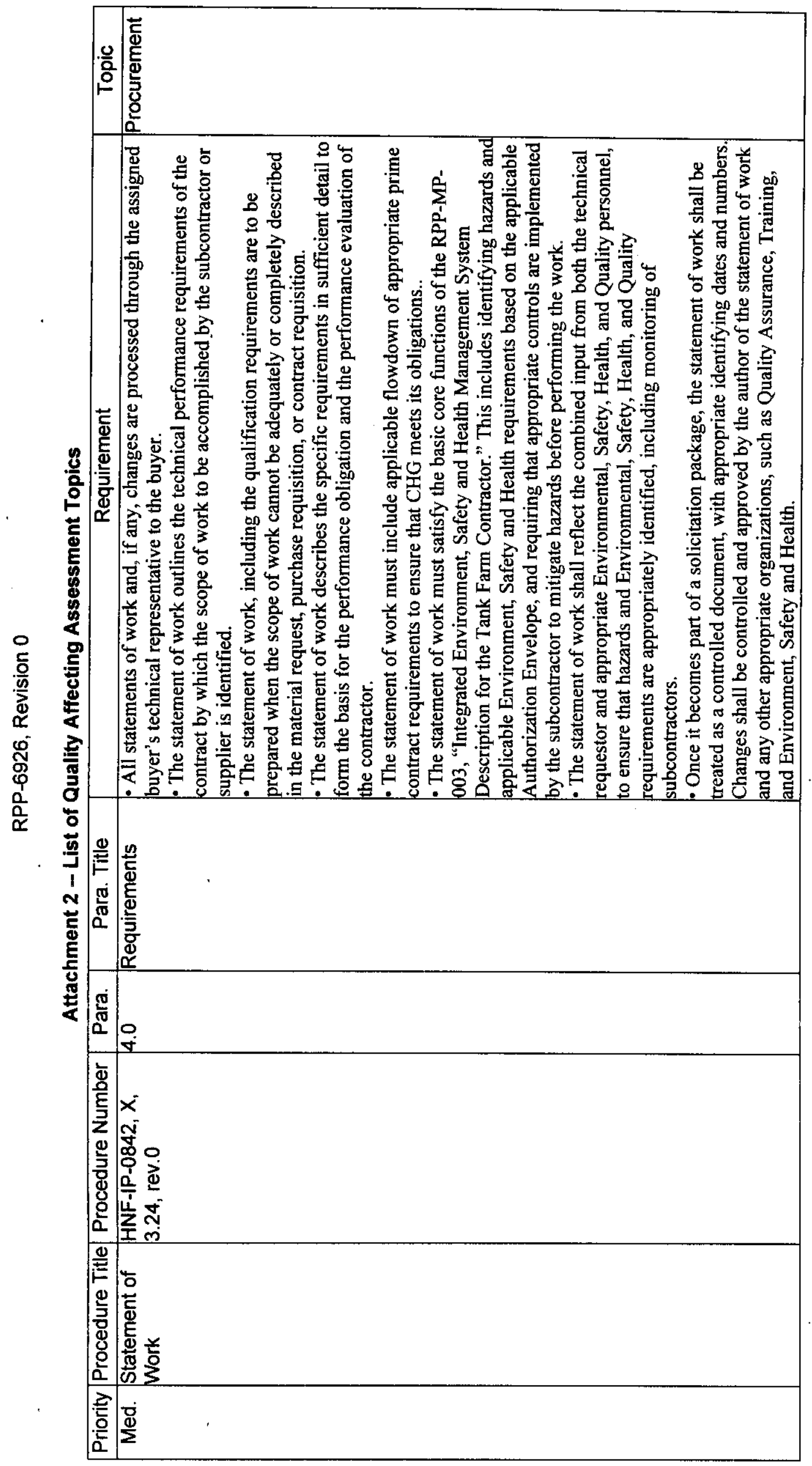




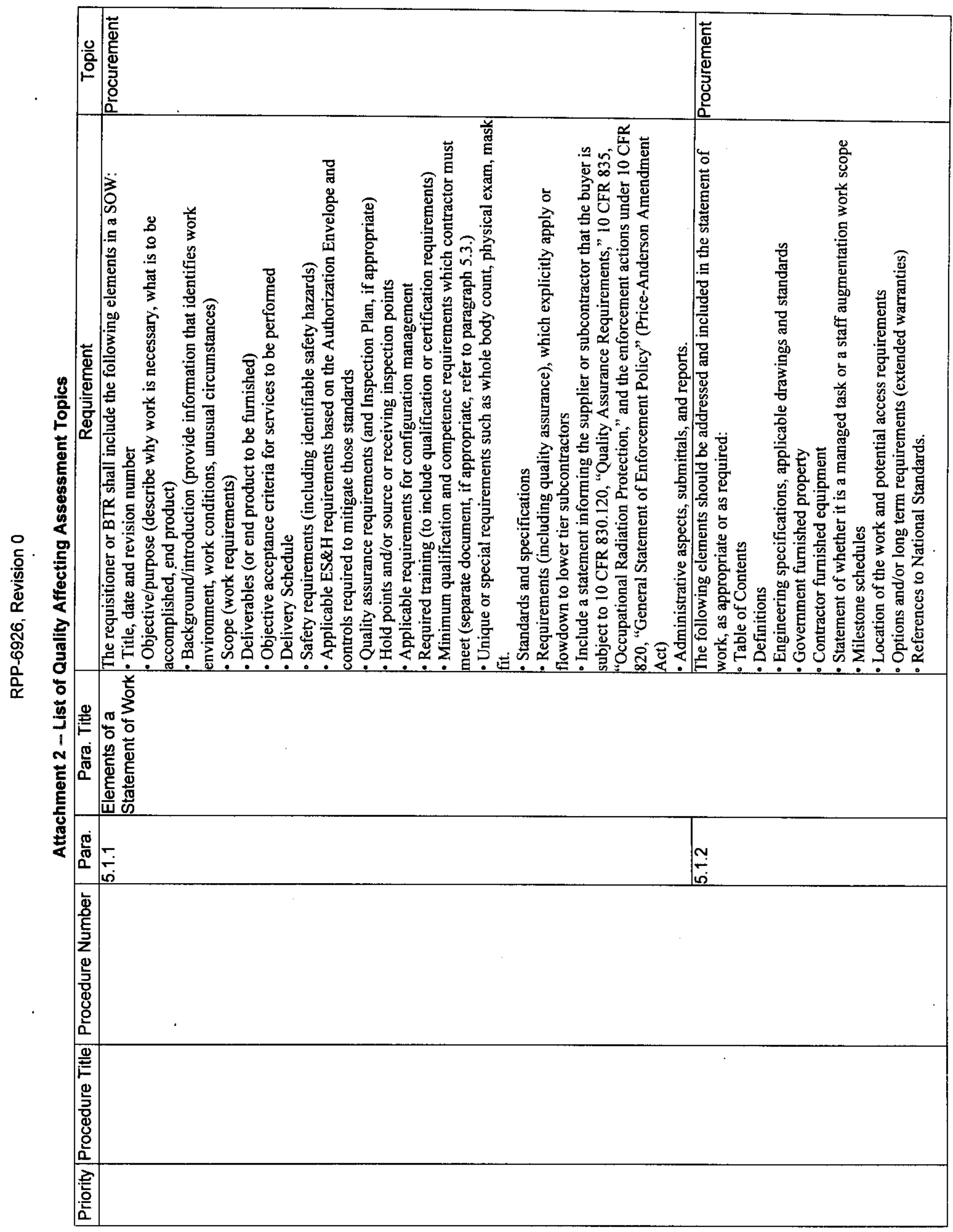




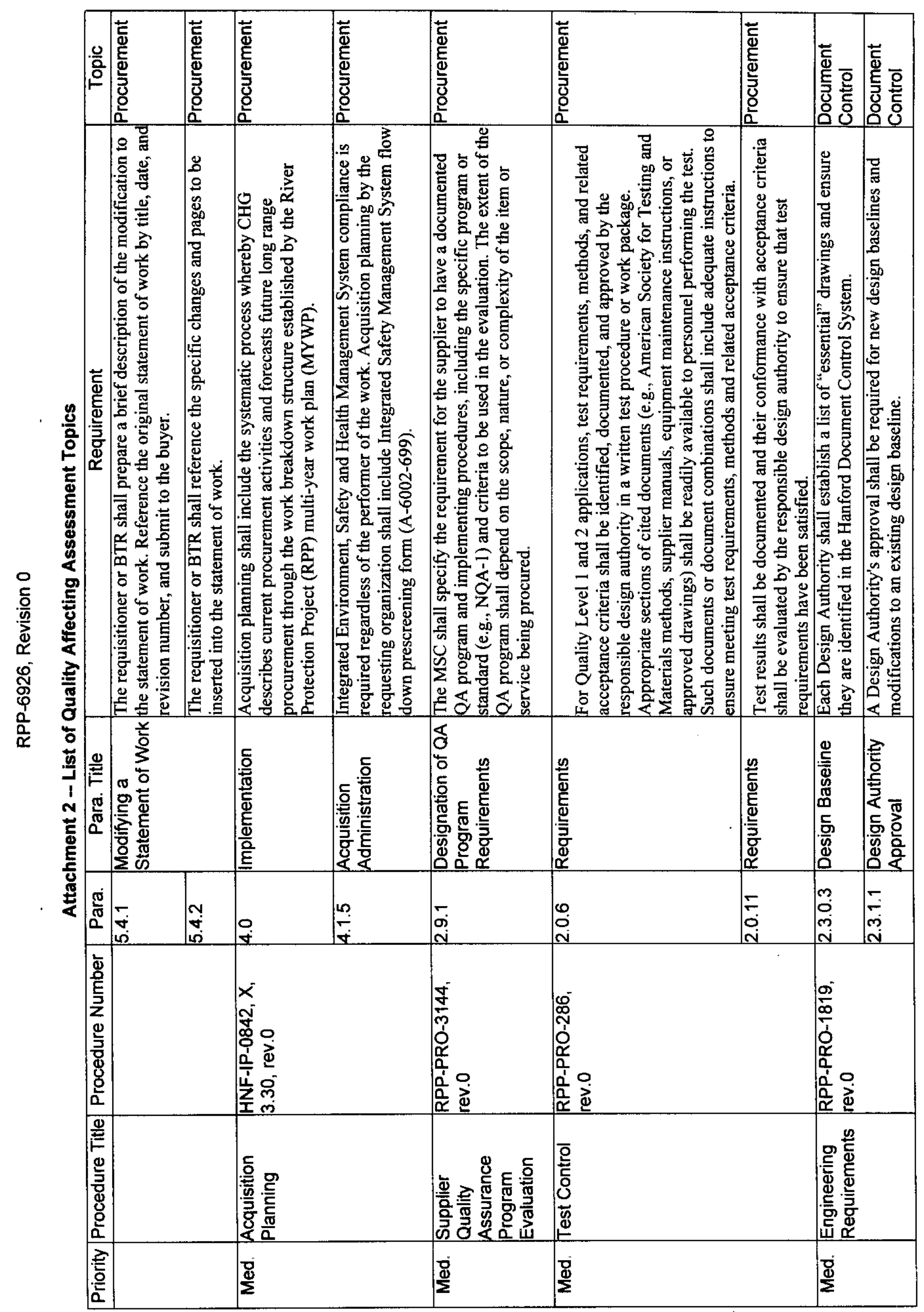




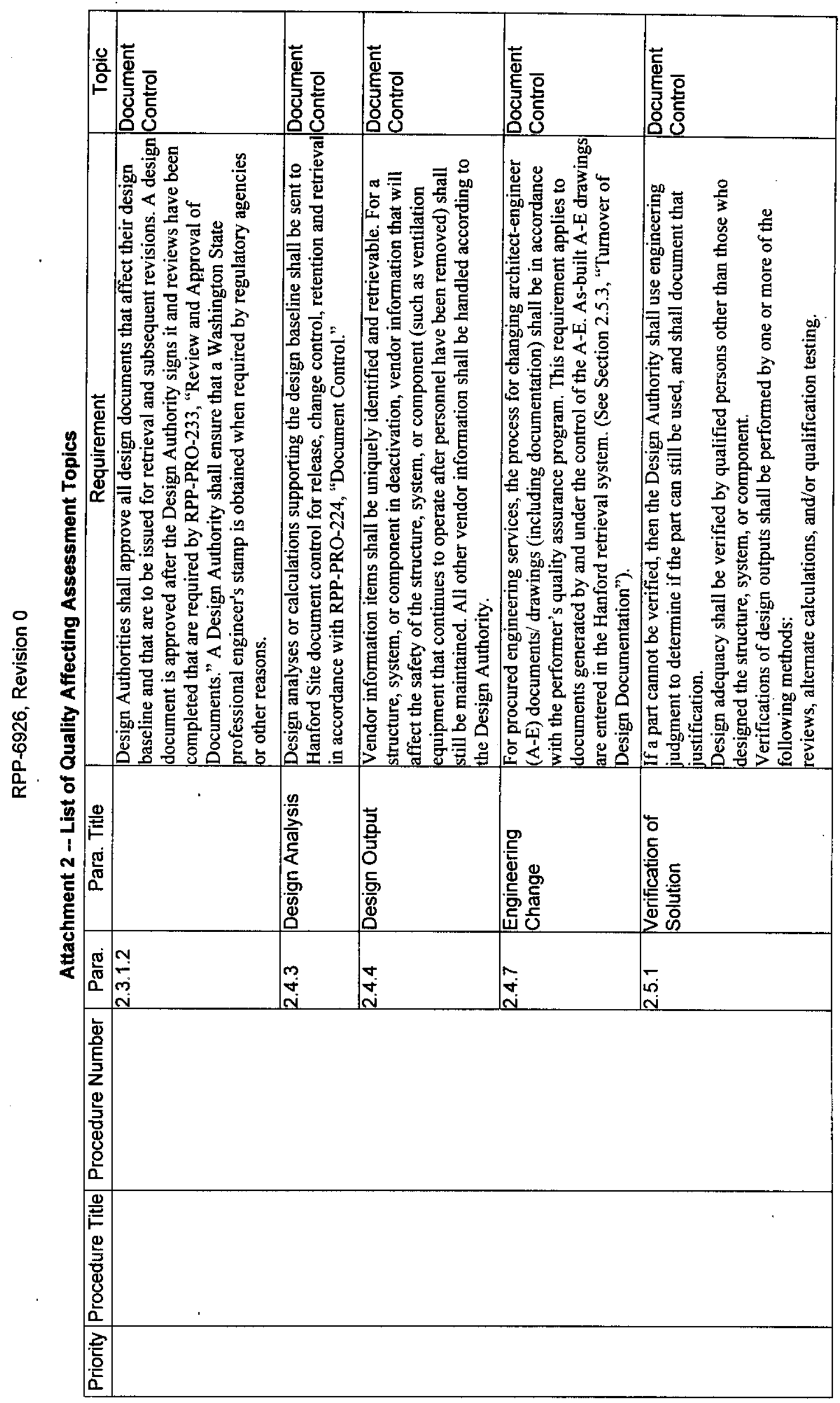




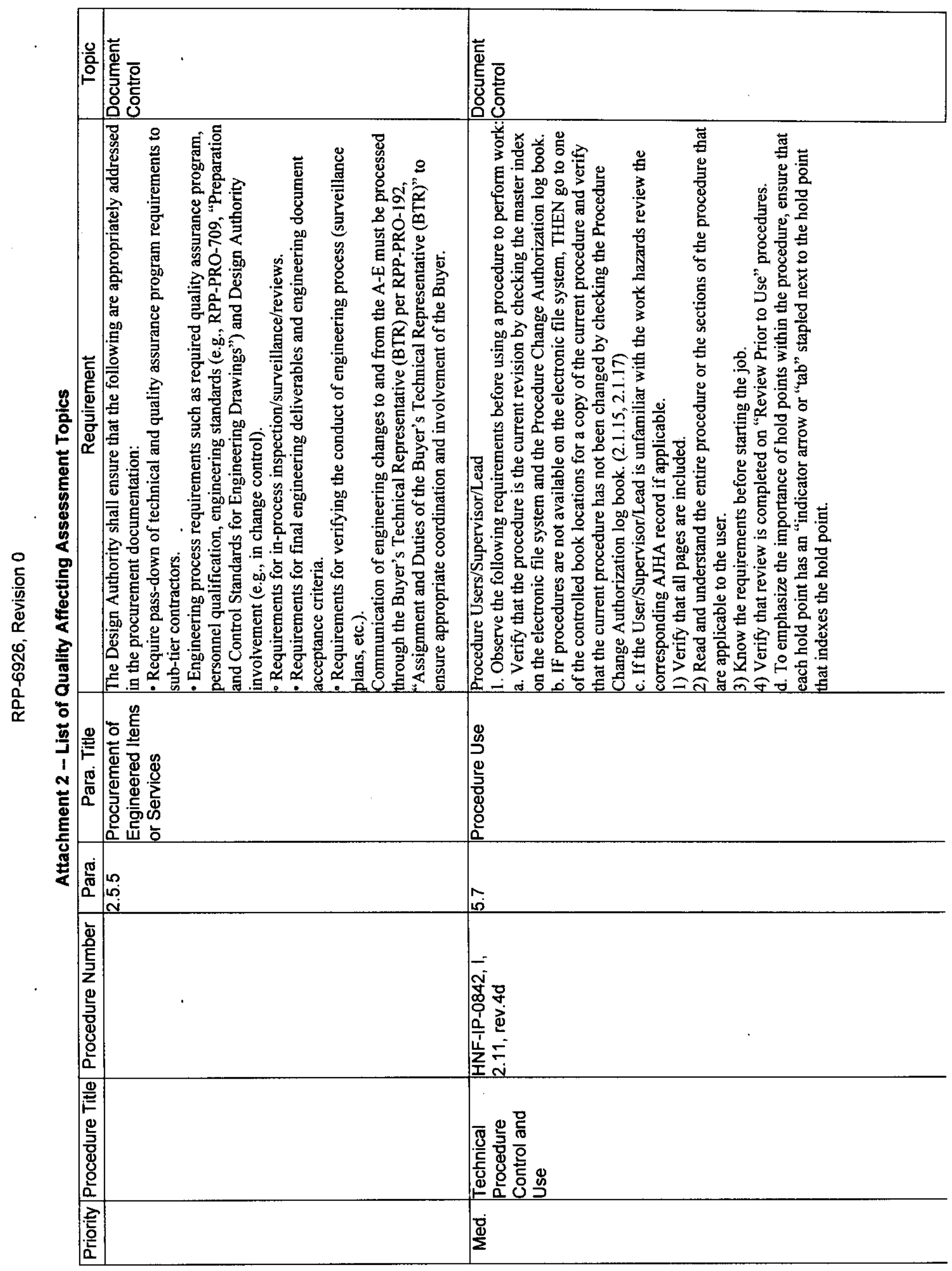









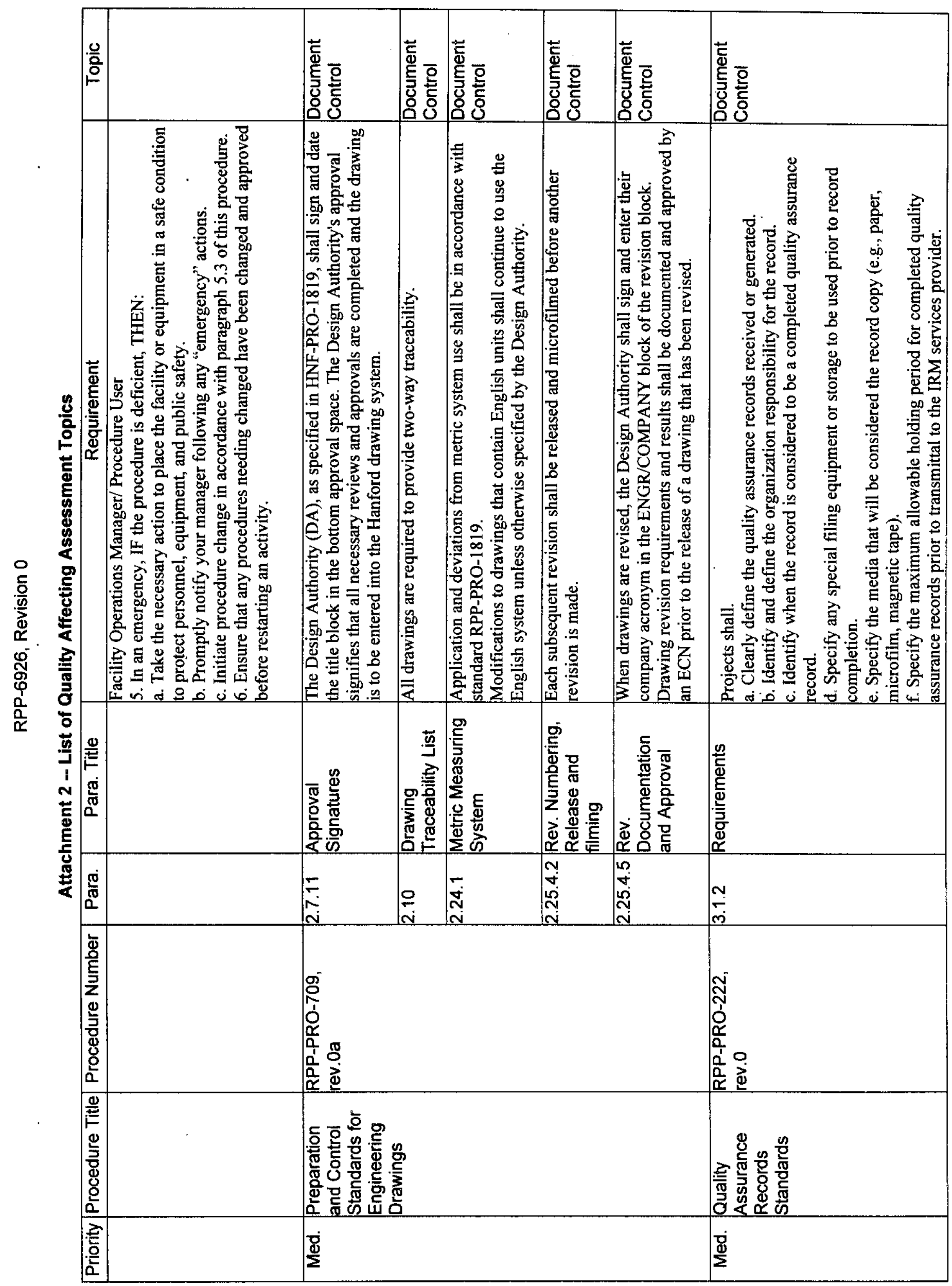




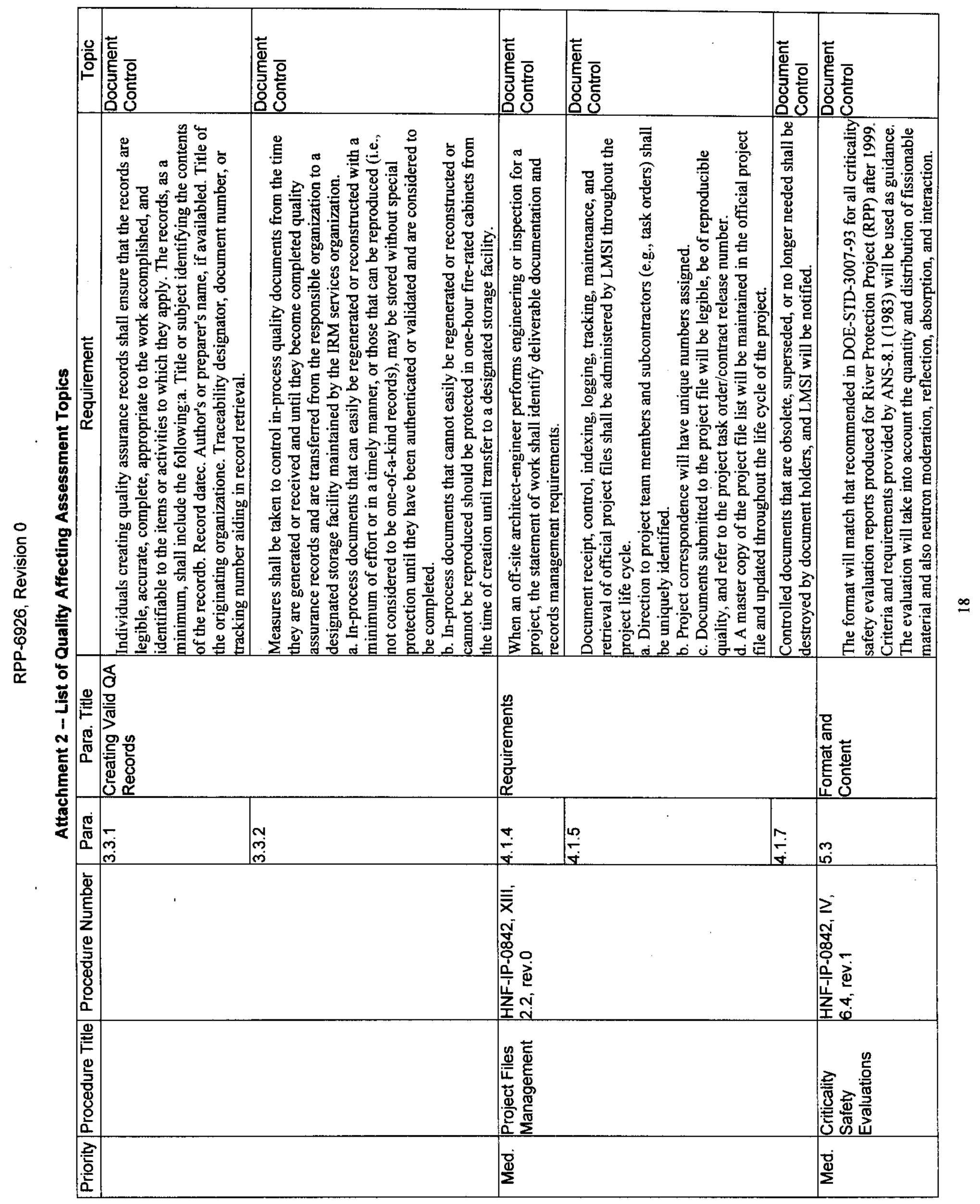




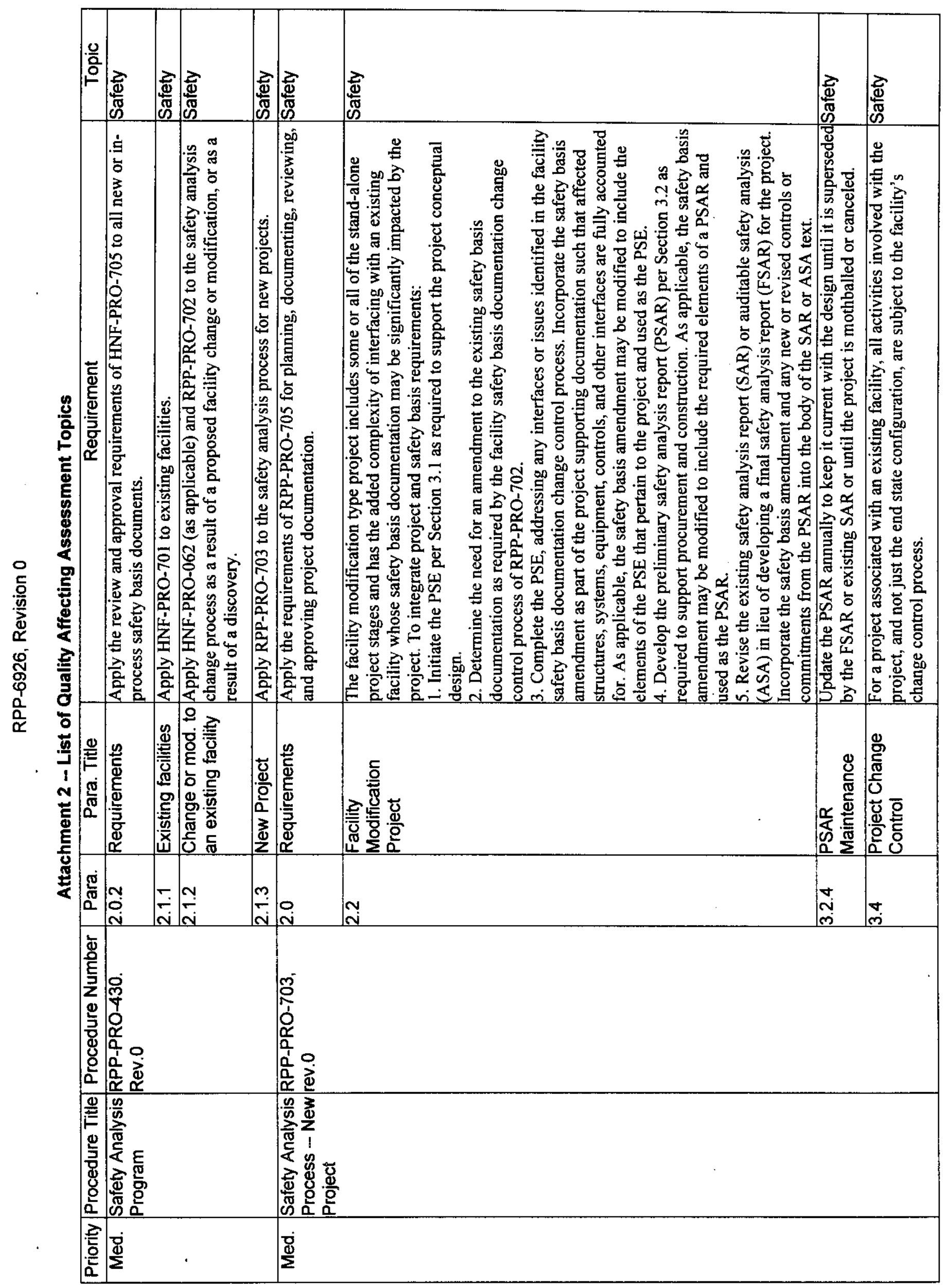




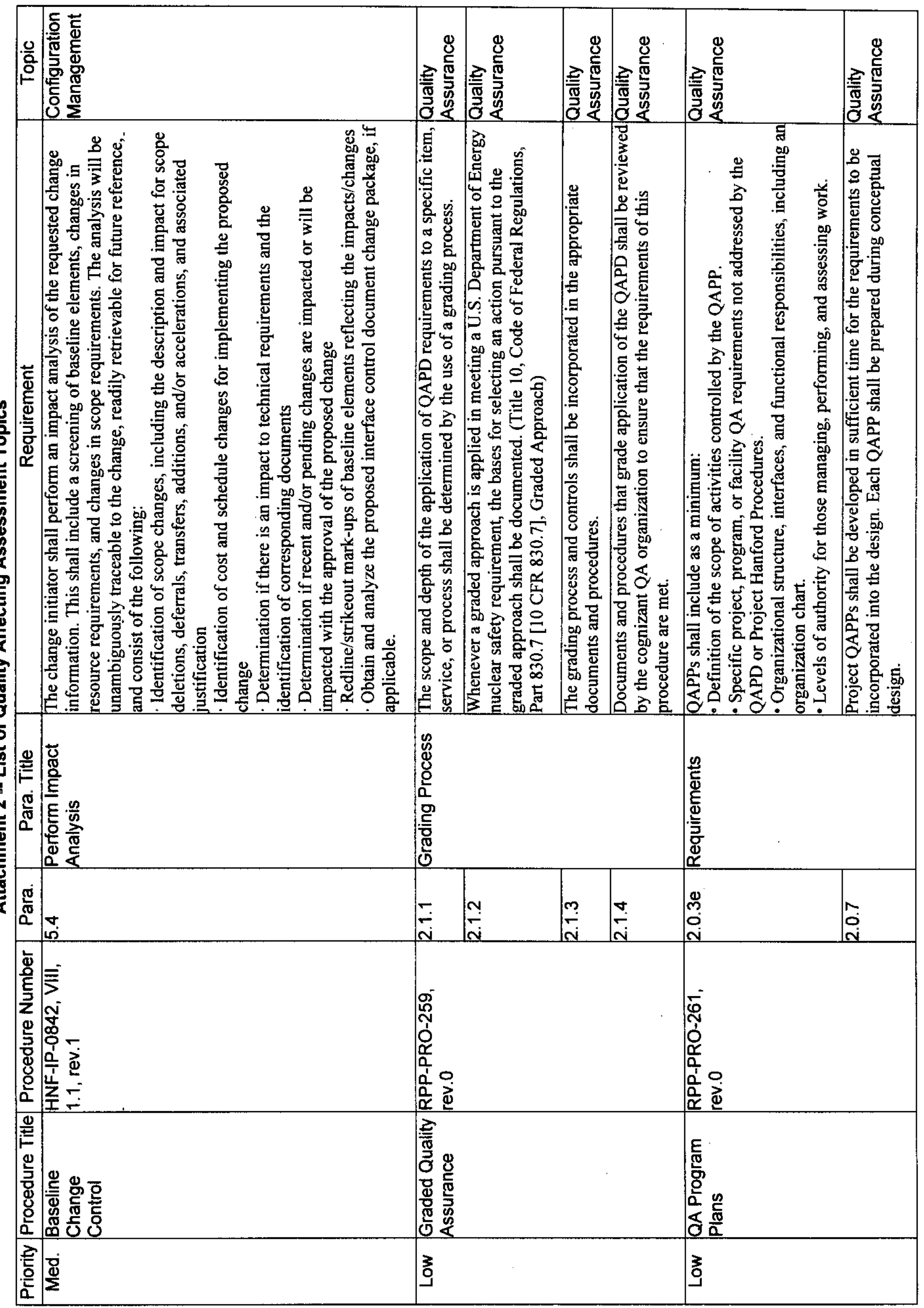




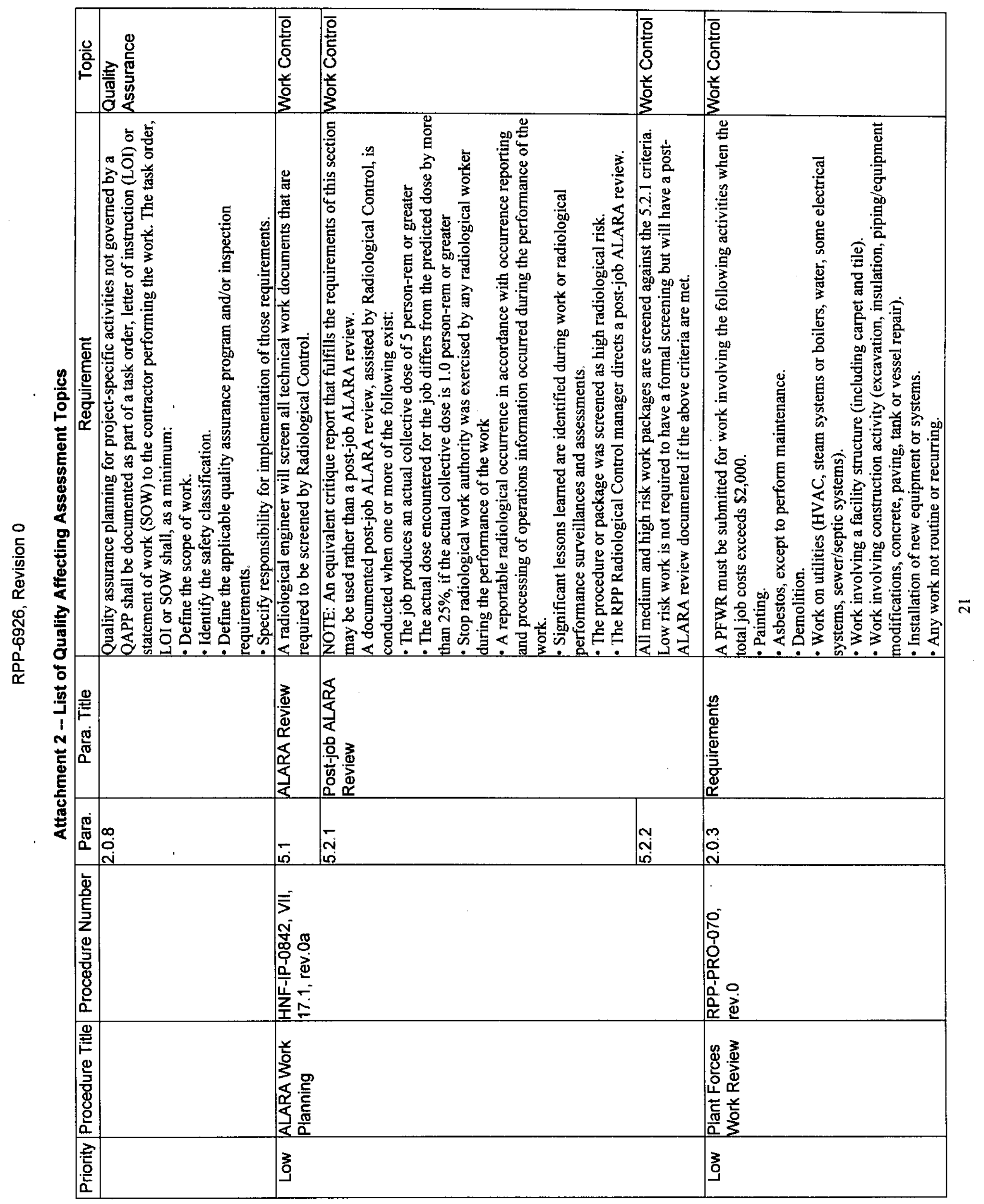




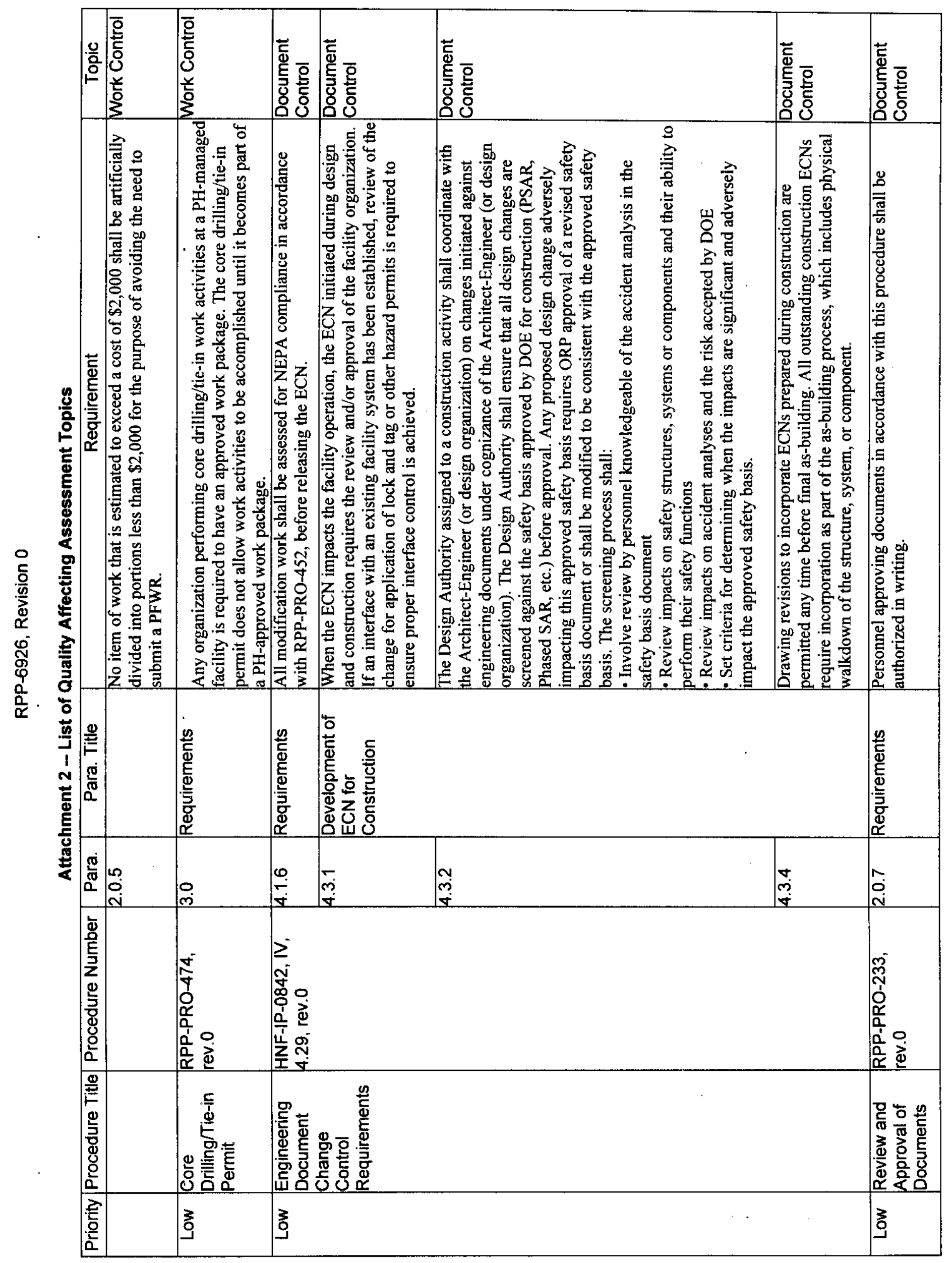

